\title{
PENAMBAHAN TEPUNG Gracilaria sp. TERHADAP KARAKTERISTIK PRODUK TERPILIH BAKSO IKAN NILA (Oreochromis niloticus)
}

\section{THE ADDITION OF Gracilaria sp. POWDER ON THE CHARACTERISTICS OF SELECTED PRODUCT TILAPIA (Oreochromis niloticus) MEATBALLS}

\author{
Yuliati Hotmauli Sipahutar", Hasby Arif Alhadi, Ahmad Ali Arridho, M. Chairil Asyurah, Kisfina Kilang, \\ dan Nina Azminah \\ Politeknik Ahli Usaha Perikanan \\ Jl. AUP Pasar Minggu, Jakarta Selatan \\ E-mail : yuliati.sipahutar@gmail.com
}

(Diterima: 15 Juni 2020; Diterima setelah perbaikan: 29 September 2021; Disetujui: 29 September 2021)

\begin{abstract}
ABSTRAK
Penelitian ini bertujuan untuk mengetahui efek penggunaan bahan tambahan makanan tepung Gracilaria $s p$. terhadap karakteristik hedonik produk bakso nila terpilih. Rumput laut Gracilaria sp. diperoleh langsung dari budidaya rumput laut di perairan Kabupaten Karawang. Penelitian ini dilakukan eksperimen rancangan acak lengkap (RAL) dengan perlakuan penambahan lima konsentrasi tepung rumput laut Gracilaria $s p .0 \%$, $6 \%, 12 \%, 18 \%$, dan $24 \%$, dengan tiga kali ulangan. Parameter uji dilakukan dengan uji hedonik, uji kimia (kadar air, kadar abu, kadar lemak, kadar protein dan kadar serat pangan) dan uji mikrobiologi ALT, Salmonella dan Escherichia coli. Analisa data dilakukan dengan analisis deskriptif. Hasil yang terpilih untuk bakso ikan nila dengan penambahan tepung rumput laut Gracilaria sebesar 6\%, dengan nilai kenampakan 7,35, bau 7,46 , rasa 7,43, tekstur 7,48. Uji kimia diperoleh hasil kadar air $61,51 \%$, kadar abu $0,98 \%$, kadar protein 23,98\%, lemak 0,38\%, serat kasar 1,82\%. Uji mikrobiologi ALT adalah 3,3 x $10^{3}$ koloni/g, Escherichia coli negatif dan Salmonella negatif. Penambahan tepung Gracilaria sp. sebagai bahan tambahan untuk bakso akan meningkatkan tekstur bakso ikan nila.
\end{abstract}

KATA KUNCI : Bakso ikan nila; mutu hedonik; tepung Gracilaria sp

\begin{abstract}
This research was aimed to observe the effect of using food additives from Gracilaria sp. powder towards hedonic characteristics of selected tilapia meatballs product. Gracilaria sp. seaweed was obtained directly from seaweed cultivation in the of Karawang waters. The research was conducted with a completely randomized design experiment (CRD) with the addition of five concentrations of Gracilaria sp. flour $0 \%, 6 \%$ $12 \%, 18 \%, 24 \%$ with three replications. The test parameters were carried out by hedonic test, chemical test (moisture content, ash content, fat content, protein content and food fiber content) and microbiological tests for TPC, Salmonella and Escherichia coli. Data analysis was done by descriptive method. The hedonic test results for selected tilapia fish balls with the addition of 6\% Gracilaria sp. powder were given as follows: appearance value of 7.35, smell 7.46, taste 7.43, texture 7.48. The results of chemical test given as follows: water content $61.51 \%$, ash content $0.98 \%$, protein content $23.98 \%$, fat $0.38 \%$, crude fiber $1.82 \%$. The TPC microbial test was resulted 3,3 × $10^{3}$ colonies/g, Escherichia coli negative and Salmonella negative. The addition of Gracilaria sp. powder as an ingredient of meatballs will improve the texture of tilapia meatballs.
\end{abstract}

KEY WORDS : Tilapia meatballs; hedonic quality; Gracilaria sp. powder

\footnotetext{
\# Korespondensi: Politeknik Ahli Usaha Perikanan

E-mail: yuliati.sipahutar@gmail.com
} 


\section{PENDAHULUAN}

Gracilaria sp adalah salah satu jenis alga yang banyak dibudidayakan di perairan Indonesia, merupakan penghasil agar dan mudah dibudidayakan (Hernandez, 2017). Gracilaria sp. merupakan alga merah yang thalusnya mengandung gel sehingga mempunyai kemampuan mengikat air yang cukup tinggi. Gracilaria $s p$ juga merupakan salah satu jenis rumput laut yang dapat digunakan untuk industri seperti dalam pembuatan agar-agar dan juga obat-obatan dan selain itu juga dapat digunakan untuk makanan dan minuman (Anggadiredja, 2011). Rumput laut terutama dari kelas Rhodopycea, seperti Gracilaria, Sargassum dan Gellidium menghasilkan agar sebagai produk utama. Dalam bidang industri, agar dimanfaatkan antara lain: industri makanan dan minuman, kosmetik, keramik, farmasi, kertas, fotografi, pakan ternak, cat, tekstil, (Suparmi \& Sahri, 2009). Agar banyak digunakan dalam industri makanan seperti industri permen, keju, es krim, susu coklat, jelly, serta pengalengan daging dan ikan (Agustang et al., 2021) .

Pemanfaatan rumput laut sebagai bahan tambahan merupakan suatu alternatif untuk menghasilkan produk makanan yang memiliki nilai gizi (Sahubawa \& Ustadi, 2014). Kandungan gizi rumput laut sebagai sumber serat pangan yang memiliki nilai sebesar $78,94 \%$. Selain serat pangan, kandungan gizi rumput laut di antaranya adalah vitamin A (beta karoten), B1, B2, B6, B12, C dan niacin, serta mineral yang penting seperti kalsium dan zat besi (Chapman \& Chapman, 1980). Kandungan agar dan proksimat rumput laut Gracilaria sp. terdiri dari karbohidrat 61,38\%; protein $15,38 \%$; lemak $1,8 \%$; air $17,6 \%$; abu $4,38 \%$, agar $31,4 \%$ (Yudiati et al., 2020). Nurhajar (2021) menyatakan bahwa rumput laut Gracilaria sp. memiliki kandungan karbohidrat yaitu $41,68 \%$, protein $6,59 \%$, lemak $0,68 \%$, air $9,73 \%$, abu $32,76 \%$, dan serat $8,92 \%$. Menurut Norziah dan Ching, (2000) kandungan kimia pada Gracilaria changgi adalah protein 6,9\%; lemak 3,3\%; serat $24,7 \%$; kadar abu $22,7 \%$ dan vitamin C $28,5 \mathrm{mg} /$ $100 \mathrm{~g}$.

Masyarakat Indonesia dapat menumbuhkan kebiasaan mengkonsumsi ikan dengan mengembangkan berbagai produk olahan hasil perikanan, sebagai upaya peningkatan gizi masyarakat. Bakso ikan adalah salah satu di antara penganekaragaman usaha dari produk perikanan. Menurut SNI 7266:2014, bakso ikan adalah produk olahan hasil perikanan menggunakan surimi atau lumatan daging yang dicampur tepung dan bahan-bahan lainnya, kemudian dibentuk dan dipanaskan (Badan Standardisasi Nasional, 2014)

Pemanfaatan rumput laut perlu dikembangkan sebagai bahan tambahan makanan pembentuk gel, yaitu dengan cara penambahan tepung Gracilaria sp. sebagai bahan tambahan pada bakso ikan untuk meningkatkan tekstur bakso. Berdasarkan penelitian Stefany (2013), penambahan tepung Gracilaria gigas pada karakteristik bakso ikan patin menghasilkan kekuatan gel 3.112,09 g.cm. Penelitian Sipahutar, et al., (2020) bahwa ekado ikan nila yang paling disukai oleh konsumen dengan penambahan tepung Gracilaria sp. $4 \%$ dalam hal kenampakan, bau, rasa dan tekstur.

Penelitian tentang penambahan rumput laut pada produk jelly fish telah banyak dilakukan di antaranya adalah Sipahutar et al., (2021) dengan penambahan tepung Gracilaria sp konsentrasi 0\%, 3\%, 6\%, 9\%, dan $12 \%$ pada sosis ikan nila.

Penelitian ini bertujuan untuk melanjutkan pemanfaatan tepung Gracilaria sp. yang digunakan sebagai pembentuk tekstur pada bakso ikan nila, dan mendapatkan produk terpilih dengan penambahan konsentrasi rumput laut $0 \%, 6 \%, 12 \%, 18 \%$, dan $24 \%$. Manfaat penelitian ini memberikan informasi kepada masyarakat tentang Gracilaria sp. sebagai bahan tambahan makanan yang aman untuk menggantikan boraks sebagai pengenyal yang dapat membahayakan kesehatan.

\section{BAHAN DAN METODE}

\section{Alat dan Bahan}

Alat yang yang digunakan adalah silent cutter (Maksindo), neraca analitik (Vibra AJ), pan stainless steel, hot plate (thermo scientific cimarec HP 13153033Q), Oven Laboratorium (Memmert UN 260 ), Kjeldahl Analisis Nitrogen Otomatis Laboratorium, Micro Burette (Duran), Beaker Glass $250 \mathrm{ml}$ (Pyrex), Labu Takar $100 \mathrm{ml}$ (Pyrex), Pipet $1 \mathrm{ml}$ (Pyrex), Gelas Ukur $250 \mathrm{ml}$ (Pyrex), erlenmeyer $250 \mathrm{ml}$ (Pyrex), Autoclave Ls 50 LJ, inkubator laboratory.

Bahan yang digunakan adalah tepung Gracilaria sp, surimi ikan nila, air, dan es, tepung tapioka, garam, gula, lada, penyedap rasa, bawang putih, dan putih telur, $\mathrm{NaOH} 7 \%$ (Merck), $\mathrm{HCl} 5 \%$ (Merck), $\mathrm{NaCl} 85 \%$ (Merck), alkohol 70\%, $\mathrm{H}_{2} \mathrm{SO}_{4}$ (Merck), Methyl Red Indicator ORI DFW660, Plate Count Agar (PCA) (Merk), Peptone Powder Bacto (Merck).

\section{Metode}

Penelitian ini dilakukan dengan eksperimen penambahan tepung rumput laut Gracilaria sp. dengan 5 konsentrasi yaitu $0 \%, 6 \%, 12 \%, 18 \%$, dan $24 \%$ dengan 3 kali ulangan. Proses pembuatan bakso ikan mengacu pada SNI 7266-2014 tentang bakso ikan (BSN, 2014), dengan sedikit modifikasi yaitu penambahan tepung Gracilaria sp.

Metode penelitian menggunakan rancangan acak lengkap dengan dua kali ulangan, parameter 
organoleptik dengan uji hedonik. Analisis data dilakukan dengan deskriptif. Uji hedonik dilakukan untuk mengukur tingkat preferensi suatu produk dengan menggunakan lembar penilaian skala hedoni berkisar 1-9. Bakso ikan dinilai oleh 30 panelis yang semi terlatih dan tidak terlatih yang dipilih secara acak, yang sudah cukup mengenal bakso ikan (BSN, 2006d). Bakso ikan diuji hedonik untuk menentukan produk terpilih, setelah didapatkan produk terpilih, dilanjutkan dengan uji mutu kimia dan mikrobiologi.

Parameter uji kimia dengan parameter kadar air SNI 2354.2:2015 (BSN, 2015), kadar abu SNI 2354.1:
2010 (BSN, 2010), kadar protein SNI 01-2354.4-2006 (BSN, 2006e). Kadar lemak SNI 01-2354.3-2006 (BSN, 2006d), Kadar serat kasar SNI 01-2891-1992 (BSN, 1992).

Parameter uji mikrobiologi dengan parameter Angka Lempeng Total SNI 01-2332.3-2006 (BSN, 2006b), Escherichia coli SNI 01-2332.1-2006 (BSN, 2006a). Salmonella SNI 01-2332.2-2006 (BSN, 2006b).

Rancangan percobaan dengan 5 perlakuan konsentrasi dapat dilihat komposisi adonan bakso ikan per unit percobaan pada Tabel 1.

Tabel 1. Komposisi adonan bakso ikan per unit percobaan

Table 1. Fish meatball composition per unit experiment

\begin{tabular}{llllll}
\hline \multirow{2}{*}{ Bahan-Bahan } & \multicolumn{5}{c}{ Komposisi } \\
\cline { 2 - 6 } & $\mathrm{A}$ & $\mathrm{B}$ & $\mathrm{C}$ & $\mathrm{D}$ & $\mathrm{E}$ \\
\hline Surimi (ikan nila) & $250 \mathrm{~g}$ & $250 \mathrm{~g}$ & $250 \mathrm{~g}$ & $250 \mathrm{~g}$ & $250 \mathrm{~g}$ \\
Bawang putih & $3 \mathrm{siung}$ & $3 \mathrm{siung}$ & $3 \mathrm{siung}$ & $3 \mathrm{siung}$ & $3 \mathrm{siung}$ \\
Tepung tapioka & $50 \mathrm{~g}$ & $50 \mathrm{~g}$ & $50 \mathrm{~g}$ & $50 \mathrm{~g}$ & $50 \mathrm{~g}$ \\
Garam & $7 \mathrm{~g}$ & $7 \mathrm{~g}$ & $7 \mathrm{~g}$ & $7 \mathrm{~g}$ & $7 \mathrm{~g}$ \\
Lada bubuk & $0,5 \mathrm{~g}$ & $0,5 \mathrm{~g}$ & $0,5 \mathrm{~g}$ & $0,5 \mathrm{~g}$ & $0,5 \mathrm{~g}$ \\
Air es & Secukupnya & Secukupnya & Secukupnya & Secukupnya & Secukupnya \\
Putih telur & $1,5 \mathrm{sendok}$ & 1,5 sendok & 1,5 sendok & 1,5 sendok & 1,5 sendok \\
Penyedap rasa & $10 \mathrm{~g}$ & $10 \mathrm{~g}$ & $10 \mathrm{~g}$ & $10 \mathrm{~g}$ & $10 \mathrm{~g}$ \\
Tepung Gracilaria & $0 \%$ & $6 \% ;$ & $12 \%$ & $18 \%$ & $24 \%$ \\
\hline
\end{tabular}

Keterangan : Penambahan berdasarkan berat daging ikan

\section{HASIL DAN BAHASAN}

Pengujian mutu bakso dengan perlakuan penambahan tepung Gracilaria sp. dengan konsentrasi yang berbeda dilakukan dengan uji hedonik, uji kimia dan uji mikrobiologi.

\section{Uji hedonik}

Uji hedonik dilakukan dengan panca indera pengamat untuk menilai faktor-faktor mutu yang umumnya dikelompokkan atas penampakan, bau, cita rasa, dan tekstur (BSN, 2006b). Pengujian hedonik dilakukan oleh 30 panelis tidak terlatih. Hasil uji hedonik disajikan pada Tabel 2.

\section{Kenampakan}

Kenampakan merupakan faktor utama dalam penilaian panelis terhadap suatu produk (Soekarto, 2008). Kenampakan juga mempengaruhi penerimaan konsumen, meskipun kenampakan tidak menentukan tingkat kesukaan konsumen secara mutlak. Kenampakan adalah unsur penilaian awal seorang konsumen terhadap suatu produk pangan yang disajikan (Buckle, 2007).

Pada Tabel 2, nilai kenampakan sesuai dengan penilaian sensori bakso ikan menurut SNI 7266:2014 (Badan Standardisasi Nasional, 2014) nilai kenampakan tertinggi adalah pada sampel B (6\%) dengan nilai 7,35, dengan permukaan halus, tidak berongga dan warna cerah. Sedangkan nilai kenampakan tertinggi kedua didapatkan pada sampel A $(0 \%)$ dan C (12\%) dengan nilai 7,03 yaitu dengan permukaan kurang halus, sedikit berongga dan warna kurang cerah. Nilai kenampakan yang terendah yaitu pada sampel E (24\%) dengan nilai 6,86 dengan permukaan kasar, berongga dan agak kusam.

Penelitian Sipahutar, et al., (2020) pada penambahan tepung Gracilaria sp. pada sosis ikan kurisi menunjukkan nilai kenampakan tertinggi yaitu 8,44

Tabel 2. Hasil uji Hedonik Bakso

Table 2. Hedonic Test Results of meatballs

\begin{tabular}{llllll}
\hline \multirow{2}{*}{ Pengujian } & \multicolumn{5}{c}{ Komposisi Tepung Gracilaria } \\
\cline { 2 - 6 } & $\mathrm{A}=0 \%$ & $\mathrm{~B}=6 \%$ & $\mathrm{C}=12 \%$ & $\mathrm{D}=18 \%$ & $\mathrm{E}=24 \%$ \\
\hline Kenampakan & $7,03 \pm 0,57$ & $7,35 \pm 0,48$ & $7,03 \pm 0,05$ & $6,96 \pm 0,38$ & $6,86 \pm 0,43$ \\
Bau & $6,93 \pm 0,03$ & $7,46 \pm 0,46$ & $6,93 \pm 0,46$ & $6,90 \pm 0,20$ & $6,33 \pm 0,30$ \\
Rasa & $6,72 \pm 0,05$ & $7,43 \pm 0,46$ & $6,85 \pm 0,06$ & $6,66 \pm 0,35$ & $6,46 \pm 0,05$ \\
Tekstur & $7,14 \pm 0,66$ & $7,48 \pm 0,38$ & $6,56 \pm 0,42$ & $6,70 \pm 0,40$ & $6,47 \pm 0,38$ \\
\hline Rata-rata & 6,94 & 7,43 & 6,83 & 6,75 & 6,54 \\
\hline
\end{tabular}


pada penambahan $2,5 \%$ dengan kriteria permukaan halus, tidak berongga dan warna cerah. Sedangkan nilai terendah yaitu 6,95 diperoleh dengan penambahan $10 \%$ dengan kriteria permukaan kurang halus, sedikit berongga dan warnanya kurang cerah. Hal ini menunjukkan bahwa semakin banyak penambahan tepung Gracilaria sp., berpengaruh terhadap perubahan kenampakan dengan warna yang kurang cerah.

Penelitian Karim dan Aspari, (2015) menyatakan bahwa penambahan karagenan 2,5\% memberikan pengaruh terhadap kenampakan bakso ikan gabus yaitu tertinggi 4,73 dengan kriteria suka dan penambahan tepung karagenan $7,5 \%$ memberikan nilai terendah yaitu 3,07 dengan kriteria agak tidak suka. Hal ini menunjukkan bahwa semakin banyak penambahan tepung karagenan, berpengaruh terhadap penurunan kesukaan konsumen.

\section{Bau}

Bau adalah zat kimia yang tercampur di udara, umumnya dengan konsentrasi yang sangat rendah, yang diterima manusia dengan indra penciuman (DeMan, 2010). Penilaian bau dilakukan dengan cara mencium langsung. Bakso ikan nila yang bagus akan tercium bau spesifik ikan tanpa bau tambahan.

Pada Tabel 2, nilai bau sesuai dengan penilaian sensori bakso ikan menurut SNI 7266:2014 (Badan Standardisasi Nasional, 2014) nilai bau tertinggi adalah pada sampel B $(6 \%)$ dengan nilai 7,46 , dengan bau spesifik produk. Nilai terendah yaitu 6,33 pada sampel E (24\%) dengan bau netral. Salah satu faktor yang menentukan suatu makanan dapat diterima oleh konsumen adalah bau. Bau makanan banyak menentukan kelezatan makanan tersebut.

Penelitian Sipahutar et al., (2021) menunjukkan bahwa penambahan tepung Gracilaria sp. 3\% pada bau sosis ikan nila didapatkan nilai tertinggi dari panelis yaitu 7,6 dengan spesifikasi sangat suka. Nilai terendah yaitu 6,53 dengan spesifikasi suka pada penambahan tepung Gracilaria sp. 6\%. Menurut Princestasari dan Amalia, (2015) pada formulasi rumput laut Gracilaria sp. dalam pembuatan bakso daging sapi, nilai bau tertinggi yaitu 5 pada penambahan tepung Gracilaria sp. 30\% dengan kriteria suka. Penambahan tepung Gracilaria sp. $40 \%$ memberikan nilai terendah yaitu 4 dengan kriteria agak suka. Nurhuda, et al, (2017) tentang penambahan tepung karagenan 0,5\% terhadap bakso ikan manyung, menunjukkan nilai bau 5,6. Penambahan karagenan 2,5\% dengan nilai bau 6,1 memiliki bau ikan yang khas dan juga bau dari rempahrempah. Hal ini menunjukkan bahwa penambahan tepung Gracilaria sp tidak memberikan perbedaan pada bau bakso ikan dengan kriteria suka dan sangat suka.

\section{Rasa}

Rasa merupakan faktor penentu daya terima konsumen terhadap produk pengolahan (Susiwi, 2009). Faktor rasa memegang peranan penting dalam pemilihan produk oleh konsumen, karena walaupun kandungan gizinya baik tetapi rasa yang kurang menarik tidak dapat diterima oleh konsumen.

Pada Tabel 2, sesuai dengan penilai sensori bakso ikan menurut SNI 7266:2014 (Badan Standardisasi Nasional, 2014) nilai rasa tertinggi yaitu 7,43 pada sampel B (6\%) dengan kriteria rasa spesifik produk. Nilai rasa terendah yaitu 6,46 pada sampel E (18\%) dengan kriteria rasa spesifik produk kurang.

Hasil penelitian Permadi et al., (2019) bahwa nilai rasa dengan penambahan tepung Gracilaria sp. 1:8 pada sosis ikan bandeng menunjukkan, nilai rasa tertinggi yaitu 3,16 . Sedangkan nilai rasa 3,0 pada sosis tanpa penambahan tepung Gracilaria sp. Penelitian Sipahutar et al., (2021) bahwa penambahan tepung Gracilaria sp. $5 \%$ pada ekado ikan nila menunjukkan nilai tertinggi 7,67 dan tanpa penambahan tepung Gracilaria memberikan nilai rasa terendah 7,52 . Hal ini menunjukkan bahwa penambahan tepung Gracilaria sp memberikan perbedaan pada bau bakso ikan dengan kriteria bau spesifik produk hingga rasa spesifik produk kurang.

Menurut Princestasari dan Amalia, (2015) penambahan konsentrasi tepung Gracilaria sp. pada bakso sapi, tidak memberikan pengaruh pada rasa bakso baik secara hedonik maupun scoring, skala tingkat kesukaan panelis terhadap rasa berkisar antara 7,52-7,67 yaitu netral. Hal ini menunjukkan bahwa penambahan tepung Gracilaria sp tidak memberikan perbedaan pada rasa bakso dengan kriteria rasa spesifik produk. Penelitian Nurhuda et al., (2017) tentang penambahan tepung karagenan $0,5 \%$ terhadap rasa bakso ikan manyung, menunjukkan angka tertingi yaitu 6,5 dari atribut yang lainnya (kenampakan, bau, tekstur). Sedangkan penambahan karagenan 2,5\% menunjukkan nilai bau 6,2.

Bakso ikan manyung yang dihasilkan semuanya memiliki rasa ikan yang khas dan juga rasa dari rempahrempah yang cukup menonjol dan tidak terdapat rasa yang asing. Panelis memiliki tingkat kesukaan yang hampir sama terhadap bau bakso ikan nila yang ditambahkan tepung karaginan. Hal ini menunjukkan bahwa rasa merupakan kriteria terpenting untuk produk bakso ikan manyung.

Cita rasa yang dihasilkan pada bakso secara umum dipengaruhi bumbu yang digunakan. Dari segi rasa, terdapat perbedaan dari masing-masing penilaian karena nilai rasa dengan penambahan tepung Gracilaria 
$s p$. akan berbeda dengan nilai rasa tanpa penambahan tepung Gracilaria sp. Menurut Desrosier (2008), cita rasa makanan dipengaruhi oleh komponen-komponen yang terdapat di dalam makanan seperti protein, lemak, dan karbohidrat yang menyusunnya.

\section{Tekstur}

Tekstur merupakan salah satu faktor yang menentukan penerimaan suatu produk. Penilaian tekstur bertujuan untuk mengetahui penerimaan panelis terhadap tingkat elastisitas atau kekenyalan suatu produk yang dapat dinilai menggunakan indera peraba, yaitu lewat rangsang sentuhan (DeMan, 2010). Tekstur adalah salah satu sifat bahan atau produk yang dapat dirasakan melalui sentuhan kulit atau pencicipan.

Pada Tabel 2, sesuai dengan penilaian sensori bakso ikan menurut SNI 7266:2014 (Badan Standardisasi Nasional, 2014) nilai tekstur tertinggi 7,48 pada sampel B (6\%) dengan kriteria tekstur padat kompak dan kenyal. Nilai tekstur terendah yaitu 6,47 pada sampel E (24\%) dengan kriteria tekstur tidak padat, tidak kompak dan tidak kenyal.

Penelitian Princestasari dan Amalia, (2015) nilai tertinggi pada penambahan tepung Gracilaria sp. 30\% memberikan nilai 5 dengan kriteria suka dan penambahan tepung Gracilaria sp. 50\% memberikan nilai terendah yaitu 3 dengan kriteria agak tidak suka. Hal ini menunjukkan penambahan tepung Gracilaria memberikan pengaruh terhadap penurunan kesukaan konsumen. Penelitian Sipahutar, et al., (2020) bahwa penambahan tepung Gracilaria sp. 5\% pada tekstur ekado ikan nila menunjukkan nilai tertinggi 8,29 dengan kriteria padat, kompak dan kenyal. Sedangkan penambahan tepung Gracilaria 6\% memberikan nilai tekstur terendah 7,68 dengan kriteria padat, kompak dan agak kenyal. Hal ini menunjukkan semakin banyak rumput laut yang ditambahkan pada ekado ikan nila, menunjukkan tingkat kesukaan berdasarkan sensorik semakin menurun yaitu tekstur tidak padat, tidak kompak dan tidak kenyal serta mudah pecah.

Sesuai penelitian Karim dan Aspari, (2015) bahwa dengan penambahan tepung karagenan 7,5\% terhadap bakso ikan gabus menunjukkan nilai tekstur tertinggi yaitu 4,33, dengan kriteria suka hingga sangat suka, sedangkan perlakuan tanpa penambahan tepung karagenan ( $0 \%$ ) menunjukkan nilai terendah yaitu 3,20 dengan kriteria kurang suka hingga netral. Hal ini menunjukkan hasil uji hedonik penambahan karagenan memberikan pengaruh pada tekstur bakso ikan gabus. Diduga penambahan tepung Gracilaria sp. yang terlalu banyak dapat mengikat molekul air terlalu banyak sehingga menjadi basah menyebabkan tekstur yang dihasilkan cenderung menjadi lebih lembut (Sipahutar, et al., 2020).
Hasil nilai hedonik bakso ikan nila terpilih adalah penambahan tepung Gracilaria sp. 6\%. Nilai rata-rata hedonik produk terpilih adalah 7,43 terdiri dari nilai kenampakan 7,35 ; nilai bau 7,46 ; nilai rasa 7,43 dan nilai tekstur 7,48 .

\section{Pengujian Kimia Produk Terpilih}

Produk bakso ikan yang terpilih adalah produk B dengan penambahan tepung Gracilaria sp. konsentrasi $6 \%$, selanjutnya diuji kimia dan mikro untuk mengetahui mutunya.

Pengujian bakso ikan dilakukan dengan acuan pada SNI 7266:2014 diperoleh hasil yang disajikan dalam Tabel 3.

\section{1) Kadar Air}

Pada Tabel 3 menunjukkan penambahan tepung Gracilaria 6\% diperoleh kadar air bakso ikan nila adalah 61,51\%. Berdasarkan SNI 7266:2014, nilai kadar air bakso ikan maksimal yaitu sebesar $65 \%$ sehingga kadar air yang dihasilkan sudah memenuhi persyaratan mutu dan keamanan pangan.

Hasil penelitian Sipahutar et al., (2021) pada sosis ikan nila dengan penambahan tepung Gracilaria sp. 3\% menunjukkan kadar air 58,77 \%. Pada sosis ikan bandeng dengan perbandingan lumatan daging ikan bandeng berbanding dengan tepung Gracilaria sp 1:8 menunjukkan kadar air sebesar 71,26\% (Permadi et al., 2019). Pada sosis ikan lemuru dengan penambahan tepung Gracilaria sp 20\% menghasilkan kadar air 63,2\% dan penambahan tepung Gracilaria sp. $80 \%$ menghasilkan kadar air 69,68\%. Hal ini menunjukkan pada sosis ikan lemuru. adanya peningkatan kadar air setiap peningkatan rasio rumput laut Gracilaria sp (Yaska et al., 2017). Rumput laut Gracilaria sp. merupakan polisakarida yang bersifat hidrofilik sehingga dapat meningkatkan kadar air jika ditambahkan dalam suatu produk (Gufram \& Kordi, 2011).

Kadar air bakso ikan menentukan daya awet bahan pangan tersebut. Kadar air yang terlalu tinggi di atas 65\% mengakibatkan mudahnya mikroorganisme untuk berkembang biak sehingga akan terjadi perubahan baik dari segi warna, aroma, rasa, dan tekstur. Hal ini sesuai dengan kadar air di bawah $65 \%$, membuat pertumbuhan mikroorganisme makin lambat ber-

Tabel 3. Hasil Pengujian Proksimat bakso terpilih

Table 3. Result of Proximate testing of selected meatballs

\begin{tabular}{lcc}
\hline \multicolumn{1}{c}{ Pengujian } & SNI & Produk terpilih \\
\hline Kadar Air & Maksimal 65\% & $61,51 \%$ \\
Kadar Abu & Maksimal 2,0\% & $0,98 \%$ \\
Kadar Protein & Minimal 7\% & $23,48 \%$ \\
Kadar lemak & - & $2,38 \%$ \\
Kadar serat kasar & - & $1,82 \%$ \\
\hline
\end{tabular}


kembang biak, sehingga proses pembusukan akan berlangsung lebih lambat (Winarno, 2014).

\section{2) Kadar $\mathrm{Abu}$}

Pada Tabel 3 dapat dilihat bakso ikan nila dengan penambahan tepung Gracilaria 6\% menunjukkan kadar abu adalah 0,98\%. Berdasarkan SNI 7266:2014, nilai kadar abu bakso ikan nila maksimal yaitu sebesar 2,0\% sehingga kadar abu yang dihasilkan memenuhi persyaratan mutu dan keamanan pangan. Kadar abu pada bakso ikan ini berasal dari kandungan mineral yang terdapat pada ikan nila dan garam yang ditambahkan.

Penelitian Yaska et al., (2017) pada sosis ikan lemuru dengan penambahan tepung Gracilaria sp 20\% menghasilkan kadar abu 2,29\% dan penambahan tepung Gracilaria sp. $80 \%$ menghasilkan kadar abu 2,38\%. Penelitian Sipahutar, et al., (2020) pada sosis ikan kurisi dengan penambahan tepung Gracilaria $s p$ 2,5\% menunjukkan kadar abu 1,52\% dan penambahan tepung Gracilaria sp. 10\% dengan kadar abu 1,74\%. Dengan demikian semakin banyak jumlah rumput laut Gracilaria sp. yang ditambahkan menyebabkan kadar abu sosis ikan kurisi meningkat. Kadar abu merupakan campuran antara komponen anorganik atau mineral yang terdapat pada fosfor, kalsium, selenium zat besi, iodium, magnesium dan natrium.

\section{3) Kadar Protein}

Pada Tabel 3 menunjukkan penambahan tepung Gracilaria sp 6\% menunjukkan kadar protein bakso ikan adalah 23,48\%. Berdasarkan SNI 7266:2014, nilai kadar protein bakso ikan minimal sebesar $7 \%$. Hal ini menunjukkan kadar protein yang dihasilkan memenuhi persyaratan mutu dan keamanan pangan.

Penelitian Yakhin et al., (2013) dengan penambahan tepung Gracilaria sp 0,50\% pada sosis ikan lele menunjukkan kadar protein 11,18\% sedangkan kadar protein pada sosis komersial adalah 9,47\%. Hal ini menunjukkan bahwa dengan penambahan tepung Gracilaria sp akan menaikkan kadar protein sosis ikan lele.

Penelitian Sipahutar et al., (2020) tentang penambahan tepung Gracilaria sp. 2,5\% terhadap sosis ikan kurisi menunjukkan kadar protein 13,17\%, dan penambahan tepung Gracilaria sp. 10\% menunjukkan kadar protein 13,28\%. Penelitian Yaska et al., (2017) dengan penambahan tepung Gracilaria sp $20 \%$ pada sosis ikan lemuru menunjukkan kadar protein 7,24\% dan penambahan tepung Gracilaria sp. 80\% menunjukkan kadar protein 7,67\%. Hal ini menunjukkan semakin banyak rumput laut yang ditambahkan pada sosis ikan kurisi berpengaruh terhadap kenaikan kadar protein.

\section{4). Kadar Lemak}

Pada Tabel 3 menunjukkan penambahan tepung Gracilaria sp $6 \%$ pada kadar lemak bakso ikan nila adalah 2,38\%. Berdasarkan SNI 7266:2014, nilai kadar lemak bakso ikan tidak ditentukan jumlahnya.

Penelitian Yaska et al., (2017) dengan penambahan tepung Gracilaria sp $20 \%$ pada sosis ikan lemuru menunjukkan kadar lemak $10,7 \%$ dan penambahan tepung Gracilaria sp. $80 \%$ menunjukkan kadar lemak $18,73 \%$.

Hasil penelitian Buggi et al., (2015) penambahan rumput rumput laut Eucheuma cottoni $5 \%$ pada bakso ikan lele adalah $2,76 \%$ sedangkan penambahan rumput laut Eucheuma cottoni 10\% adalah 3,32\%. Penelitian Sipahutar et al., (2020) tentang penambahan tepung Gracilaria sp. 2,5\% terhadap sosis ikan kurisi menunjukkan kadar lemak $0,62 \%$, dan penambahan tepung Gracilaria sp. $10 \%$ menunjukkan kadar lemak $0,66 \%$. Dengan demikian semakin banyak jumlah rumput laut Gracilaria sp. yang ditambahkan menyebabkan kadar lemak meningkat. Penambahan rumput laut Gracilaria sp. dapat meningkatkan kestabilan emulsi pada sosis ikan lemuru.

Emulsi lemak dapat stabil karena peran agar yang terkandung dalam rumput laut Gracilaria sp. Dengan stabilnya emulsi lemak pada bakso maka keluarnya lemak dari jaringan daging pada bakso selama perebusan dapat dicegah. Dengan begitu kadar lemak pada bakso dapat dipertahankan (Fennema's, 2008) Lemak adalah suatu ester asam lemak dengan gliserol yang berbentuk padat dalam suhu kamar, tidak mempunyai ikatan rangkap sehingga mempunyai titik lebur yang tinggi (Winarno, 2014).

\section{5). Kadar serat kasar}

Pada Tabel 3 menunjukkan penambahan tepung Gracilaria sp 6\% pada kadar serat bakso ikan nila adalah 1,82 . Serat-serat yang terdapat dalam bahan pangan yang tidak tercerna mempunyai sifat positif bagi gizi dan metabolisme. Dietary fiber merupakan komponen dari jaringan tanaman yang tahan terhadap proses hidrolisis oleh enzim dalam lambung dan usus kecil (Winarno, 2014).

Penelitian Yakhin et al., (2013) pada sosis ikan lele dengan penambahan tepung Gracilaria gigas. 0,50\% menunjukkan kadar serat yang larut adalah $4,68 \%$ dan sosis komersial menunjukkan kadar serat terlarut adalah $1,33 \%$. Sedangkan pada pada serat yang tidak larut dengan penambahan tepung Gracilaria gigas $0,50 \%$ adalah $24,32 \%$ dan sosis komersial pada serat yang tidak larut adalah $14,65 \%$. Hal ini menunjukkan pemberian tepung rumput laut Gracilaria gigas 
memberikan kandungan serat yang lebih tinggi dibandingkan sosis ikan komersial. Bubuk rumput laut meningkatkan kandungan serat makanan dalam sosis ikan lele karena mengandung agarosa, serat pangan dapat bermanfaat bagi pencernaan manusia.

Rumput laut Gracilaria sp. mempunyai kadar serat kasar cukup tinggi mencapai 10,51\% (Anggadiredja, 2011). Secara kimia rumput laut Gracilaria sp. terdiri dari protein $(5,4 \%)$, karbohidrat $(33,3 \%)$, lemak $(8,6 \%)$ serat kasar (3\%) dan abu $(22,25 \%)$. Selain itu juga mengandung asam amino, vitamin, dan mineral seperti natrium, kalium, kalsium, iodium, zat besi dan magnesium (Patawari, 2018). Menurut Astawan, (2004) rumput laut Eucheuma cottoni secara kimia terdiri dari abu 29,97\%; protein 5,91\%; lemak 0,28\%; karbohidrat $63,84 \%$; serat pangan total $78,94 \%$.

\section{Pengujian Mikrobiologi Produk Terpilih}

Hasil pengujian mikrobiologi produk bakso ikan yang terpilih dengan penambahan tepung Gracilaria $s p$. konsentrasi 6\%, disajikan pada Tabel 4 .

\section{1) Angka Lempeng Total (ALT)}

Hasil uji ALT pada Tabel 4 adalah 3,3 x 1033 koloni/g dengan ambang batas sesuai SNI adalah $5 \times 10^{5}$ koloni/ g (Badan Standardisasi Nasional, 2015d). Dapat disimpulkan mutu bakso ikan dengan penambahan tepung Gracilaria 6\% masih di bawah ambang batas dan memiliki mutu yang baik. Berdasarkan hal tersebut maka bakso ikan nila layak dikonsumsi. Hasil penelitian Sipahutar dan Siregar, (2016) pada bakso ikan tuna dengan penambahan karagenan 5\% adalah $5,0 \times 10^{3}$ koloni/g masih sesuai SNI 2714:2009. Hal ini menunjukkan bahwa bakso ikan tuna dengan penambahan karagenan memenuhi syarat untuk dikonsumsi.

\section{2) Escherichia coli}

Pada Tabel 4 dapat dilihat bakteri Escherichia coli pada bakso ikan nila adalah negatif. Pengujian ini dilakukan dengan 2 tahap. Tahap pertama yaitu uji pendugaan dengan menggunakan media LTB (Lauryl Tryptose Broth). Pengujian dilakukan untuk mengetahui apakah terdapat mikroorganisme pada sampel bakso ikan dengan melihat indikator ada atau tidaknya gelembung pada media dalam waktu 1x24 jam (Badan Standardisasi Nasional, 2015b). Hasil yang diperoleh, tampak adanya gelembung pada 9 tabung reaksi. Kemudian dilanjutkan dengan uji pendugaan, pada sampel didapatkan mikroba yang mampu memfermentasikan laktosa. Dapat dilihat terdapat gas pada tabung durham yang dihasilkan mikroba tersebut. Hal ini terjadi karena adanya mikroba pembentuk gas (Fardiaz, 2008).

Tahap kedua dilanjutkan dengan uji penegasan menggunakan media BGLB (Brilliant Green Lactose Broth) dan EC Broth. Setelah proses inkubasi selama 48 jam, diperoleh data bahwa dari 9 tabung menunjukkan hasil negatif. Ini berarti tidak terdapat mikroorganisme gram positif pada sampel bakso ikan melainkan bakteri golongan kolon, sehingga masih memenuhi persyaratan mutu dan keamanan pangan. Ray dan Bhunia (2007) menyatakan bakteri E. coli mati setelah pemanasan pada suhu $70^{\circ} \mathrm{C}$ selama 3,5 detik. Perlakuan pemanasan pada mikroorganisme pada suhu dan waktu pemanasan tertentu dapat mengalami heatshock, sublethally injured, atau kematian.

\section{3) Salmonella}

Pada Tabel 4 dapat dilihat pada bakso ikan, hasil uji bakteri Salmonella adalah negatif. Hal ini menunjukkan bakso ikan nila tersebut memenuhi persyaratan mutu dan keamanan pangan (Badan Standardisasi Nasional, 2015c). Badan Kesehatan Dunia (WHO) menyatakan Salmonella adalah genus bakteri yang merupakan penyebab utama penyakit bawaan makanan di seluruh dunia. Fardiaz (2008) menyatakan adanya bakteri Salmonella pada sampel bakso ikan disebabkan oleh dua faktor yaitu faktor internal dan faktor eksternal yang dapat mengakibatkan diare atau gastroenteritis.

\section{KESIMPULAN}

Bakso ikan nila dengan penambahan tepung Gracilaria sp sebesar 6\% dari bobot surimi merupakan perlakuan yang paling disukai dibandingkan perlakuan lainnya.

\section{DAFTAR PUSTAKA}

Agustang, Mulyani, S., \& Indrawati, E. (2021). Budidaya Rumput Laut (Potensi Perairan Kabupaten Sinjai, Sulawesi selatan) (S. Bahri \& A. Jumain (eds.); 1 st ed.). CV. Berkah Utami.

Anggadiredja, J. T. (2011). Rumput Laut. Penebar

Tabel 4. Hasil uji Mikrobiologi bakso terpilih

Table 4. Selected meatball microbiology test result

\begin{tabular}{llc}
\hline \multicolumn{1}{c}{ Pengujian } & \multicolumn{1}{c}{ SNI } & Hasil \\
\hline ALT & Maks $5 \times 10^{5}$ koloni $/ \mathrm{g}$ & $3,3 \times 10^{3}$ koloni $/ \mathrm{g}$ \\
Escherichia coli & $<3 \mathrm{APM} / \mathrm{g}$ & Negatif \\
Salmonella & Negatif $/ 25 \mathrm{~g}$ & Negatif \\
\hline
\end{tabular}


Swadaya.

Astawan, M. (2004). Pemanfaatan Karagenan (Eucheuma Cottonii) Untuk Meningkatkan Kadar Iodium dan Serat Pangan pada Selai dan Dodol. Jurnal Teknologi Dan Industri Pangan, 15(1).

Badan Standardisasi Nasional. (1992). Cara uji makanan dan minuman (SNI 01-2891-1992). BSN.

Badan Standardisasi Nasional. (2006). Cara uji kimia Bagian 4: Penentuan kadar protein dengan metode total nitrogen pada produk perikanan (SNI 012354.4-2006). BSN.

Badan Standardisasi Nasional. (2010). Cara uji kimia Bagian 1/: Penentuan kadar abu dan abu tak larut dalam asam pada produk perikanan (SNI 2354.1 : 2010). BSN.

Badan Standardisasi Nasional. (2014). SNI Bakso Ikan (SNI 7266-2014). BSN.

Badan Standardisasi Nasional. (2015a). Cara uji kimia - Bagian 2/ : Pengujian kadar air pada produk perikanan (SNI 2354.2:2015). BSN.

Badan Standardisasi Nasional. (2015b). Cara uji mikrobiologi Bagian 1/: Penentuan Coliform dan Escherichia coli pada produk perikanan (SNI 012332.1-2015). BSN.

Badan Standardisasi Nasional. (2015c). Cara Uji Mikrobiologi Bagian 2: Penentuan Salmonella pada Produk Perikanan (SNI 01-2332.2-2015). BSN.

Badan Standardisasi Nasional. (2015d). Cara Uji Mikrobiologi Bagian 3: Penentuan Angka Lempeng Total (ALT) pada Produk Perikanan (SNI 01-2332.32015). BSN.

Badan Standardisasi Nasional. (2015e). Pedoman pengujian sensori pada produk perikanan (SNI No. 2346:2015). BSN.

Badan Standardisasi Nasional. (2017). Cara uji kimia Bagian 3: Penentuan kadar lemak total pada produk perikanan (SNI 01-2354.3-2017).

Buckle, K. A. (2007). Ilmu Pangan. UI Press.

Buggi, S. O., Yusra, \& Efendi, Y. (2015). Mutu Bakso ikan lele (Clarias Batrachus) yang diperkaya dengan Rumput laut (Eucheuma cottoni). Prosiding Hasil Penelitian, 8(2), 400.

Chapman, V. J., \& Chapman, D. J. (1980). Seaweed and Their Uses (3rd ed.). Netherlands: Springer.

DeMan, J. M. (2010). Kimia Makanan (2nd ed.). Institut Teknologi Bandung.

Desrosier, N. W. (2008). Teknologi Pengawetan Pangan. Universitas Indonesia.

Fardiaz, D. (2008). Penuntun Praktikum Mikrobiologi Pangan. Institut Pertanian Bogor.

Fennema's. (2008). Food Science and Technology (S. Damadaran, K. Parkin, \& Owen R Fennema (eds.); fourth). CRC Press LCC.
Gufram, M., \& Kordi, H. (2011). Kiat sukses Budidaya Rumput Laut di Laut dan Tambak (1st ed.). Lily Publisher.

Hernandez, A. (2017). The Effect of Salinity on Growth of the Red Alga, Gracilaria epihippsora. Marine Science Department, University of Hawai'i at Hilo.

Karim, M., \& Aspari, D. N. F. (2015). Pengaruh Penambahan Tepung Karagenan Terhadap Mutu Kekenyalan Bakso Ikan Gabus. Jurnal Balik Diwa, 6(2), 41-49.

Norziah, M. H., \& Ching, C. Y. (2000). Nutritional composition of edible seaweed Gracilaria changgi. Food Chemistry, 68(1), 69-76. https://doi.org/ 10.1016/S0308-8146(99)00161-2

Nurhajar. (2021). Pemanfaatan rumput laut (Gracilaria sp.) untuk meningkatkan pertumbuhan dan sintasan ikan sintasa bandeng (Chanos chanos). Muhammadiyah Makasar.

Nurhuda, H. S., Junianto, \& Rochima, E. (2017). Penambahan Tepung Karaginan Terhadap Tingkat Kesukaan Bakso Ikan Manyung. Jurnal Perikanan Dan Kelautan, 8(1), 157-164.

Patawari, M. Y. (2018). Pendapatan budidaya rumput laut Gracilaria sp. di desa seppong, kecamatan Belopa Utara, Kabupaten Luwu. Jurnal Perbal, 6(2), 274-282.

Permadi, A., Wulansari, D., Tanjung, A., \& Aripudin. (2019). Pengaruh Penambahan Gracilaria sp. terhadap Mutu Sosis Ikan Bandeng (Chanos chanos). Pelagicus, 1(2), 63-70. https://doi.org/ http://dx.doi.org/10.15578/plgc.v1i2.8884 Copyright

Princestasari, L. D., \& Amalia, L. (2015). Formulasi Rumput Laut Gracilaria sp. dalam Pembuatan Bakso Daging Sapi Tinggi Serat dan Iodium. Jurnal Gizi Dan Pangan, 10(3), 185-196. https://doi.org/ 10.25182/jgp.2015.10.3.

Ray, B., \& Bhunia, A. (2007). Fundamental Food Microbiology. 4th Edition. CRC Press.

Sahubawa, L., \& Ustadi. (2019). Teknologi Pengawetan dan Pengolahan Hasil Perikanan (U. Santoso (ed.); 3rd ed.). Gajah Mada University Press.

Sipahutar, Y. H., Ma'roef, A. F. F., Febrianti, A. A., Nur, C., Savitri, N., \& Utami, S. P. (2021). Karakteristik Sosis Ikan Nila ( Oreochromis niloticus ) dengan Penambahan Tepung Rumput Laut ( Gracilaria sp ). Jurnal Penyuluhan Perikanan Dan Kelautan, 15(April), 69-84.

Sipahutar, Y. H., \& Siregar, A. N. (2016). Penambahan Konsentrasi Tepung Karagenan Pada Mutu Bakso Ikan Tuna (Thunnus sp.). Jurnal STP(Teknologi Dan Penelitian Terapan), 2, 48-55. https://www. academia.edu/41666486/Penambahan_ Konsentrasi_Tepung_Karagenan_pada_bakso_ikan_ 
Tuna_Thunnus_sp_

Sipahutar, Y. H., Siregar, A. N., Suryanto, M., Pratama, R. B., Panjaitan, T. F., \& Panjaitan, P. S. (2020). Penambahan Tepung Rumput laut (Gracilaria sp ) terhadap Karakteristik Mutu Ekado Ikan Nila ( Oreochromis niloticus ). Prosiding Seminar Nasional Online Teknologi Pangan Pascapanen, Bogor, Juni 2020, 244-249.

Sipahutar, Y. H., Taufiq, T., Kristiani, M. G. E., Prabowo, D. H. G., Ramadheka, R. R., Suryanto, M. R., \& Pratama, R. B. (2020). The Effect of Gracilaria Powder on the Characteristics of Nemipterid Fish Sausage. IOP Conference Series: Earth and Environmental Science, 404. https://doi.org/10.1088/ 1755-1315/404/1/012033

Soekarto, T. S. (2008). Penilaian Organoleptik: untuk Industri Pangan dan Hasil Pertanian. Bhrata Karya Aksara.

Stefany. (2013). Pengaruh penambahan tepung rumput laut eucheuma cottonii atau gracilaria gigas terhadap karakteristik bakso ikan patin [Universitas Pelita Harapan]. http://repository.uph.edu/ 1296/
Suparmi, \& Sahri, A. (2009). Mengenal Potensi Rumput Laut/ : Kajian Pemanfaatan Sumber Daya Rumput Laut Dari Aspek Industri Dan Kesehatan. Sultan Agung, XLIV(118), 95-116.

Susiwi, S. (2009). Penilaian Organoleptik Regulasi Pangan. Universitas Pendidikan Indonesia.

Winarno, F. (2014). Kimia Pangan dan Gizi. Gramedia.

Yakhin, L. A., Wijaya, K., \& Santoso, J. (2013). Peningkatan Kualitas Gel Sosis Ikan Lele dengan Penambahan Tepung Gracillaria gigas. Jurnal Pengolahan Hasil Perikanan Indonesia, 16(2).

Yaska, Q. I., Yusa, N. M., \& Yusasrini, N. L. (2017). Pengaruh rasio tapioka dengan rumput laut Gracilaria sp. terhadap karakteristik sosis ikan lemuru. Jurnal Ilmu Dan Teknologi Pangan (Itepa), $6(1)$.

Yudiati, E., Ridlo, A., Nugroho, A. A., Sedjati, S., \& Maslukah, L. (2020). Analisis Kandungan Agar, Pigmen dan Proksimat Rumput Laut Gracilaria sp. pada Reservoir dan Biofilter Tambak Udang Litopenaeus vannamei. Buletin Oseanografi Marina, 9(2), 133-140. https://doi.org/10.14710/ buloma.v9i2.29453 